\title{
Tren perkembangan, kondisi, permasalahan, strategi, dan prediksi komoditas peternakan Indonesia (2010- 2030)
}

\section{Development trends, conditions, problems, strategies, and forecasting of Indonesian livestock commodities (2010-2030)}

\author{
Desy Cahya Widianingrum ${ }^{1}$ dan Himmatul Khasanah ${ }^{1^{*}}$ \\ ${ }^{1}$ Program Studi Peternakan, Fakultas Pertanian, Universitas Jember, Jl. Kalimantan \\ No. 37, Jember, 68121 \\ *Email Koresponden: himma@unej.ac.id
}

\begin{abstract}
Abstrak. Tujuan penelitian ini adalah menganalisis tren perkembangan populasi dan produksi berbagai komoditas ternak di Indonesia sehingga dapat menggambarkan peluang dan tantangan serta strategi efisiensi produksi nasional. Metode penelitian ini adalah analisis deskriptif kuantitatif dan peramalan menggunakan time series expert modeler data tahun 2010-2020. Hasil penelitian ini menunjukkan bahwa produtivitas selama 10 tahun terakhir masih tergolong rendah dan belum dapat memenuhi kebutuhan nasional. Prediksi populasi ternak cenderung meningkat kecuali sapi perah dan kerbau. Produksi daging total (ruminansia dan unggas) dan telur selama 10 tahun kedepan diperkirakan meningkat, namun produksi susu cenderung stagnan. Sistem usaha peternakan secara umum masih perlu ditingkatkan. Strategi peningkatan melalui optimalisasi integrasi pakan lokal, penyediaan bibit unggul, aplikasi teknologi adaptif, implementasi pola kemitraan dan optimalisasi wilayah strategis sesuai komoditas ternak. Perbaikan tersebut diharapkan dapat menyumbang peningkatan populasi ternak ruminansia dan ungags serta produksi nasional.
\end{abstract}

Kata kunci: peramalan, produksi ruminansia dan unggas, protein hewani, swasembada

\begin{abstract}
The objective of this study was to analyze development trends of population and production of Indonesian livestock commodities as an illustration of opportunities and challenges as well as strategies for national production efficiency. The research method was carried out by quantitative descriptive analysis and forecasting using time series using expert modeler analysis data from 2010-2020. The results showed that livestock productivities for the last ten years were relatively low and have not accomplished national needs. The foresight of livestock population tends to increase, excluding dairy cattle and buffalo. Our findings predict the total production of meat (ruminants and poultry) and eggs over the next ten years to step up, but milk production tends to stagnate. Generally, the livestock production system requires to be improved. The improvement strategies were carried out by optimizing the integration of local feed, providing superior breeds, implementing adaptive technology, performing partnerships, and to optimized potential areas according to livestock commodities. These advancements were expected to contribute to an increase in the livestock and poultry population and national production.
\end{abstract}

Keywords: forecasting, livestock and poultry production, animal protein, selfsufficiency 


\author{
Widianingrum dan Khasanah \\ ANIMPRO: Conference of Applied Animal Science Proceeding Series
}

\title{
PENDAHULUAN
}

Subsektor peternakan berkontribusi penting dalam pertumbuhan dan peningkatan ekonomi di Indonesia melalui peningkatkan nilai Produk Domestik Bruto (PDB). Disisilain, adanya faktor pertumbuhan penduduk, kenaikan ekonomi, tren urbanisasi, dan perubahan preferensi dari konsumen menjadi pendukung dalam peningkatan tren kebutuhan dan permintaan produk peternakan (Delgado, Rosegrant \& Steinfeld, 2012). Tercatat produksi daging sapi nasional hanya mampu memenuhi $45 \%$ permintaan karena ada gap antara permintaan dan pasokan yang tinggi (Agus \& Widi, 2018). Kebutuhan akan daging tersebut meningkat yang sejalan dengan pertambahan populasi penduduk Indonesia yang pada tahun 2030 diprediksi akan naik 9,70\% dari tahun 2020 (BPS, 2021). Latino, Pica-Ciamarra, \& Wisser (2020) melaporkan bahwa pada tahun 2050 kebutuhan daging di negara berkembang menjadi tiga kali lipat dan dan susu menjadi dua kali lipat.

Produksi daging terutama dari ternak ruminansia, 90\% disuplai oleh peternak rakyat yang pemasarannya secara lokal dan antar kabupaten (Agus \& Widi, 2018). Daging sapi, menyumbang $11 \%$ pemenuhan kebutuhan daging nasional dan sebagian kecil $(<1 \%)$ disuplai dari daging kerbau, kambing dan domba. Kontribusi terbesar dalam pemenuhan protein hewani berasal dari daging ayam broiler yaitu mencapai $70 \%$, daging ayam buras $6,2 \%$, ayam ras petelur 2,9\% (Direktorat Jenderal Peternakan dan Kesehatan Hewan/ Ditjen PKH, 2020). Namun, harga ternak broiler hidup dan daging ayam ditingkat produsen sangat fluktuatif didominasi oleh integrator dan pengempul (Ilham, 2020). Harga produk telurpun sangat fluktuatif, hal ini disebabkan oleh kenaikan harga pakan, DOC, tren produksi telur yang cenderung menurun, adanya infeksi penyakit (Ilham, 2019). Upaya jangka pendek dan menengah pemenuhan daging dan stabilitas harga daging dilakukan pemerintah melalui import dan upaya jangka panjangnya melalui perbaikan manajemen dan penyediaan bibit unggul (Asmarantaka \& Nurmalina, 2021).

Berbeda dengan daging, kondisi produksi susu di Indonesia cenderung tetap dan harganya lebih stabil. Usaha peternakan sapi perah dilaporkan dapat bertahan dimasa pandemi Covid 19 dan bahkan mengalami peningkatan harga susu karena tingginya permintaan (Setyawan, Widianingrum, \& Yulianto, 2021). Namun, produksi susu nasional masih rendah. Faktor manajemen pemeliharaan memiliki peran dalam produktivitas sapi perah diantaranya adalah cara pemerahan dan kebersihan ternak dan kandang termasuk manajemen praktis ketika pemerahan (Khasanah \& Widianingrum, 2021). Strategi pemuliaan guna penyediaan bibit unggul harus memperhatikan tujuan, infrastruktur, program yang dijalanlan, analisispotensi genetic ternak, monitoring dan evaluais program serta kondisi lingkungan dan system produksi (Khasanah, Purnamasari dan Suciati, 2020)

Secara umum tren produk pangan asal ternak meningkat seiring kesadaran dan pemahaman masyarakat akan pangan sehat dan sumber protein hewani. Hal ini menjadikan suatu peluang tersendiri bagi sektor peternakan untuk memperbesar populasi dan produksi. Peluang tersebut juga dihadapkan pada tantangan globalisasi dan liberalisasi ekonomi dunia sehingga produksi sektor peternakan ini diharuskan untuk lebih efisien agar mampu menghadapi persaingan global (Nair, Thirunavukkarasu, \& Pandian, 2019). Manajemen dan perencanaan efektif dibutuhkan untuk dapat menyusun strategi praktis yang efisien untuk mengoptimalkan produksi ternak dan keuntungan ekonomi bagi peternak rakyat. Eksplorasi dan analisis data, identifikasi permasalahan dan startegi penyelesaian serta peramalan populasi dalam penelitian ini diharapkan mampu menggambarkan konsep komprehensif mengenai fluktuasi dan dinamika sektor peternakan, terutama perkembangan populasi dan produksi hasil ternak di dalam negeri.

\section{MATERI DAN METODE}

Penelitian ini dilaksanakan pada bulan Juni-Juli 2021 yang merupakan penelitian kuantitatif deskriptif. Penelitian ini menggambarkan tren populasi dan produksi ternak di Indonesia selama 10 tahun terakhir dan peramalan 10 tahun kedepan. Data yang digunakan adalah hasil studi literatur terhadap jumlah populasi ternak di Indonesia bersumber dari Statistik Peternaan dan Kesehatan Hewan Direktorat Jenderal Peternakan dan Kesehatan Hewan tahun 2011 sampai dengan 2020. Peramalan dianalisis menggunakan time series dengan data dalam kurun waktu 
10 tahun (2011-2020). Analisis data menggunakan pemodelan forcasting non seasonal metode Expert Modeler (SPSS 26) dengan permodelan terbaik yang dipilih (Mishra, Matuka, \& Abotaleb, 2021). Model yang digunakan dalam analisis dipresentasikan pada Tabel 1.

Tabel 1. Tipe model yang digunakan dalam analisis time series populasi ternak di Indonesia.

\begin{tabular}{cccc} 
Komoditas & Tipe Model & Komoditas & Tipe Model \\
\hline Populasi Sapi Potong & Holt & Daging Domba & Simple \\
Populasi Sapi Perah & ARIMA $(0,0,0)$ & Daging Ayam Buras & ARIMA $(0,0,0)$ \\
Populasi Kerbau & ARIMA $(0,0,0)$ & Daging Layer & Holt \\
Populasi Kambing & Holt & Daging Ayam Broiler & ARIMA $(0,1,0)$ \\
Populasi Domba & ARIMA $(0,1,0)$ & Daging Iltik & Holt \\
Populasi Ayam Buras & Holt & Daging Puyuh & ARIMA $(0,0,0)$ \\
Populasi Layer & ARIMA $(0,1,0)$ & Daging Merpati & Holt \\
Populasi Broiler & ARIMA $(0,1,0)$ & Daging Itik Manila & Holt \\
Populasi Itik & ARIMA $(0,1,0)$ & Telur ayam Buras & Brown \\
Populasi Itik Manila & Brown & Telur Layer & ARIMA $(0,1,0)$ \\
Populasi Puyuh & Holt & Telur Itik & ARIMA $(0,1,0)$ \\
Daging Sapi & ARIMA $(0,0,0)$ & Telur Puyuh & Holt \\
Daging Kerbau & ARIMA $(0,1,0)$ & Telur Itik Manila & ARIMA $(0,0,0)$ \\
Daging Kambing & Simple & & \\
\hline
\end{tabular}

\section{HASIL DAN PEMBAHASAN}

Fluktuasi jumlah populasi ternak ruminansia potong dan perah memiliki pola grafik yang hampir sama yaitu mengalami penurunan tajam pada tahun 2013 (Gambar 1). Hal ini erat kaitannya dengan program swasembada daging yang dicanangkan pada periode waktu 2000-2005, 20082010, 2010-2014. Pada Periode 2010-2014 pemerintah telah berhasil menekan impor daging yaitu berturut-turut 53\% (2011), 34.9\% (2012), 17.5\% (2013), lebih dari 10\% (2014) (Ariningsih, 2014). Indonesia juga telah berhasil memenuhi kebutuhan semen beku dan mengekspor ke berbagai negara. Namun demikian, tingginya permintaan sapi lokal menyebabkan pemotongan sapi secara besar-besaran termasuk sapi perah dan kerbau (Afrizal \& Pulungan, 2014). Program swasembada yang dicanangkan sejak tahun 2000 ini memang mengalami kegagalan pada periode I dan II (Kusmaria, Susanti, \& Fitri, 2020). Faktor penyebabnya dirangkum oleh Ariningsih (2014) diantaranya masih adanya permasalahan dibidang ketersediaan pakan, bibit, teknis budidaya dan sosio-budaya, tata niaga, masih adanya pemotongan ternak betina, ketimpangan distribusi pasokan, adanya mafia impor, serta permasalahan kesehatan.

Pemerintah berhasil menanggulangi penurunan populasi ternak sapi potong, perah, dan kerbau ditandai dengan meningkatnya grafik meskipun tidak setinggi tahun 2012 melalui program pemerintah yang senada untuk menekan impor daging. Program kedaulatan pangan berdasar Peraturan Presiden No. 2 tahun 2015) menitikberatkan salah satunya pada bidang peternakan. Upaya Khusus Percepatan Populasi Sapi dan Kerbau Bunting (UPSUS SIWAB) merupakan optimalisasi pada reproduksi yang diterapkan melalui transfer embrio (TE) atau inseminasi buatan (IB) (Rusdiana \& Soeharsono, 2017).

Populasi sapi dari tahun ke tahun terus meningkat, meskipun pada tahun 2018 terjadi sedikit penurunan sapi potong. Hal ini salah satunya disebabkan oleh aktivitas gunung Agung yang menurunkan populasi sapi Bali (Liga, Putri, \& Sumardani. 2019). Sebab lain yaitu peristiwa yang hampir sama pada tahun 2013 dimana keberhasilan penurunan impor daging sapi berpengaruh pada jumlah populasi sapi (Afrizal \& Pulungan, 2014). Namun demikian, belajar dari pengalaman menyebabkan penurunan populasi dapat diatasi dengan langkah cepat. Pada tahun yang sama, populasi kerbau menurun disebabkan peralihan fungsi lahan dan pencemaran lingkungan (Abdul, 2016). 


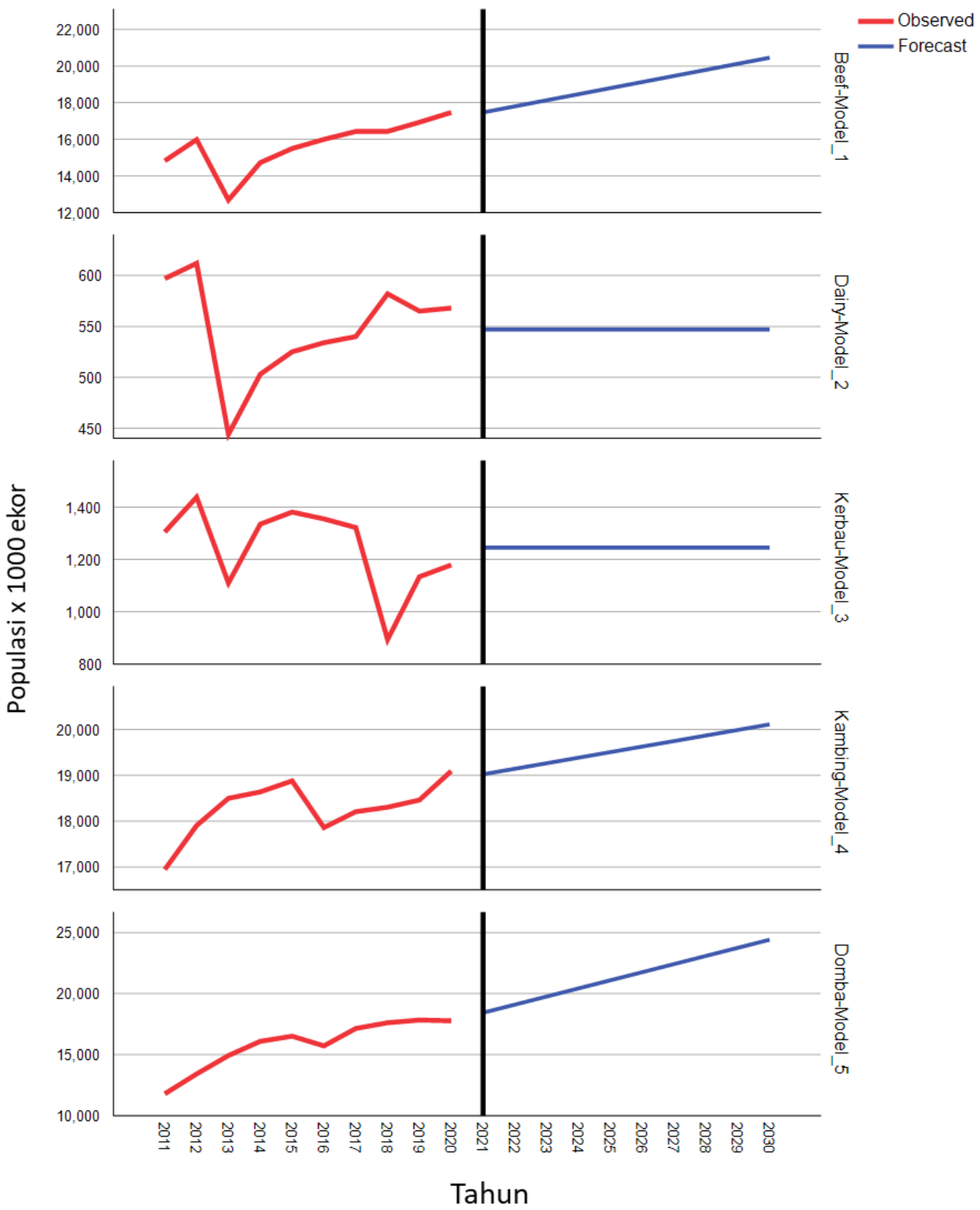

Gambar 1. Tren perkembangan populasi ternak ruminansia di Indonesia.

Jumlah populasi sapi perah tahun 2018 di Indonesia meningkat meskipun selanjutnya menurun pada tahun 2019 karena adanya pandemi Covid 19. Penurunan populasi selama wabah ini tidak disebabkan seperti analisis sebelumnya yakni permintaan daging hingga menyebabkan pemotongan ternak betina, melainkan disebabkan oleh gangguan distribusi rantai pasok subsektor hulu seperti pengadaan bibit dan pakan (Setyawan et al., 2021). Hal ini didukung oleh tren produksi susu nasional yang relatif stabil (Gambar 2) dan peningkatan konsumsi susu pada tahun 2019-2020 (Ditjen PKH 2020). Peningkatan ini dapat disebabkan karena kesadaran masyarakat dalam pemenuhan kebutuhan gizi dimasa pandemi (Saliem, Agustian, \& Perdana, 2020). 

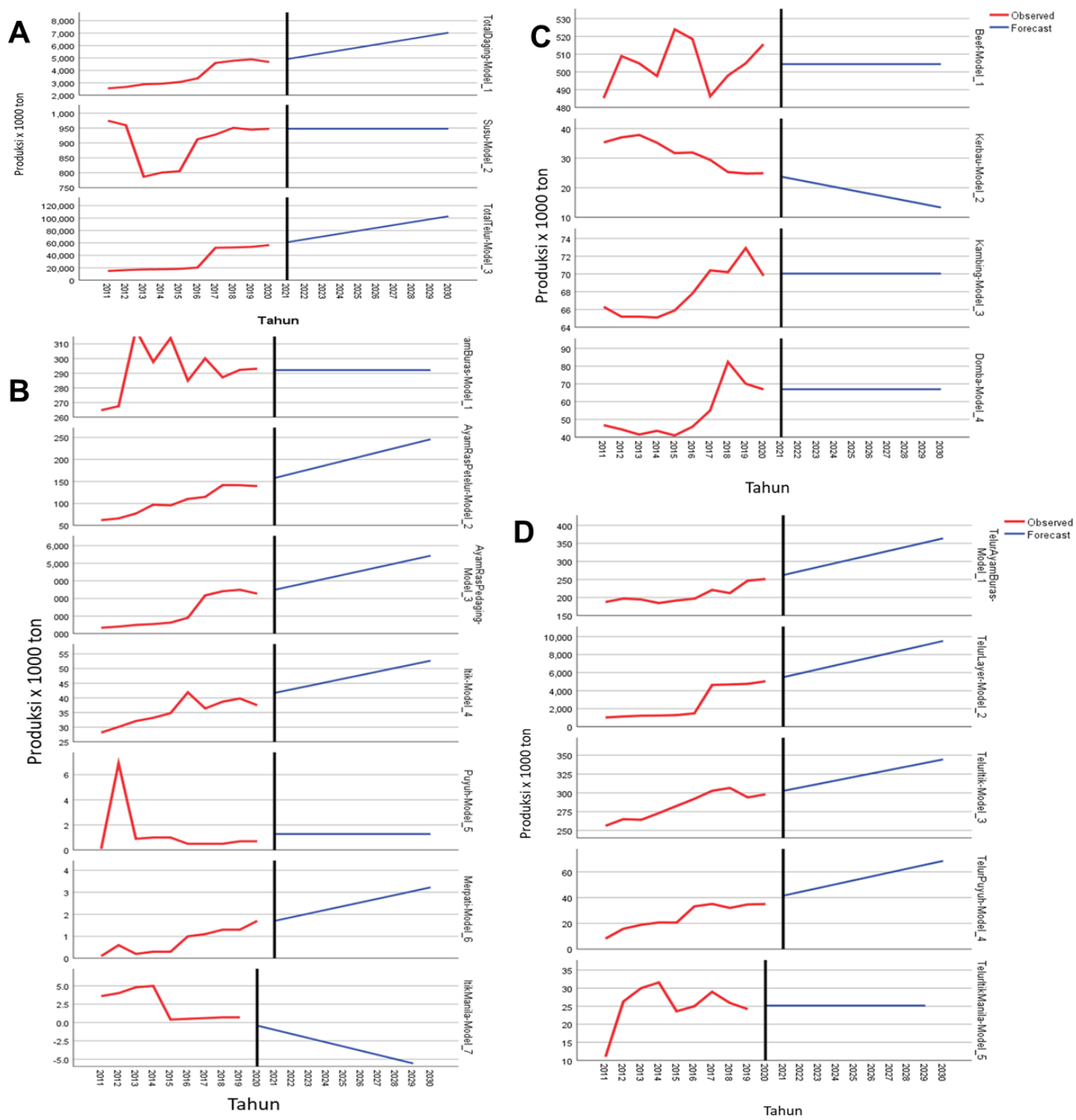

Gambar 2. Tren produksi daging, susu dan telur secara keseluruhan $(A)$, daging unggas perkomoditas (B), daging ruminansia perkomoditas (C) dan telur perkomoditas (D).

Penurunan produksi daging sapi yang terjadi tahun 2019-2020 dianalisis dipengaruhi oleh daya beli khalayak masyarakat menurun akibat pandemi, sehingga peternak membatasi jumlah pemotongan ternak (Santoso, 2020). Berdasarkan analisis meningkatnya grafik produksi dan data konsumsi telur (Ditjen PKH 2020) dapat dilihat bahwa masyarakat lebih memilih telur untuk memenuhi protein hewani dibandingkan dengan daging sapi. Prediksi produksi telur nasional akan terus meninggi hingga lebih dari 100 juta ton pada tahun 2030. Telur merupakan protein hewani yang memiliki banyak peminat dari beragam kalangan masyarakat dikarenakan harganya yang relatif ekonomis dibanding daging (Rorimpandey, Lenzun, \& Endoh, 2014). Konsumsi telur masyarakat tahun 2020 sebesar 18,16 kg/kapita (Badan Ketahanan Pangan, 2020). Dengan analisis perkiraan tersebut, maka tahun 2030 Indonesia dapat memenuhi kebutuhan telur per kapita minimal 1 butir telur sehari. 


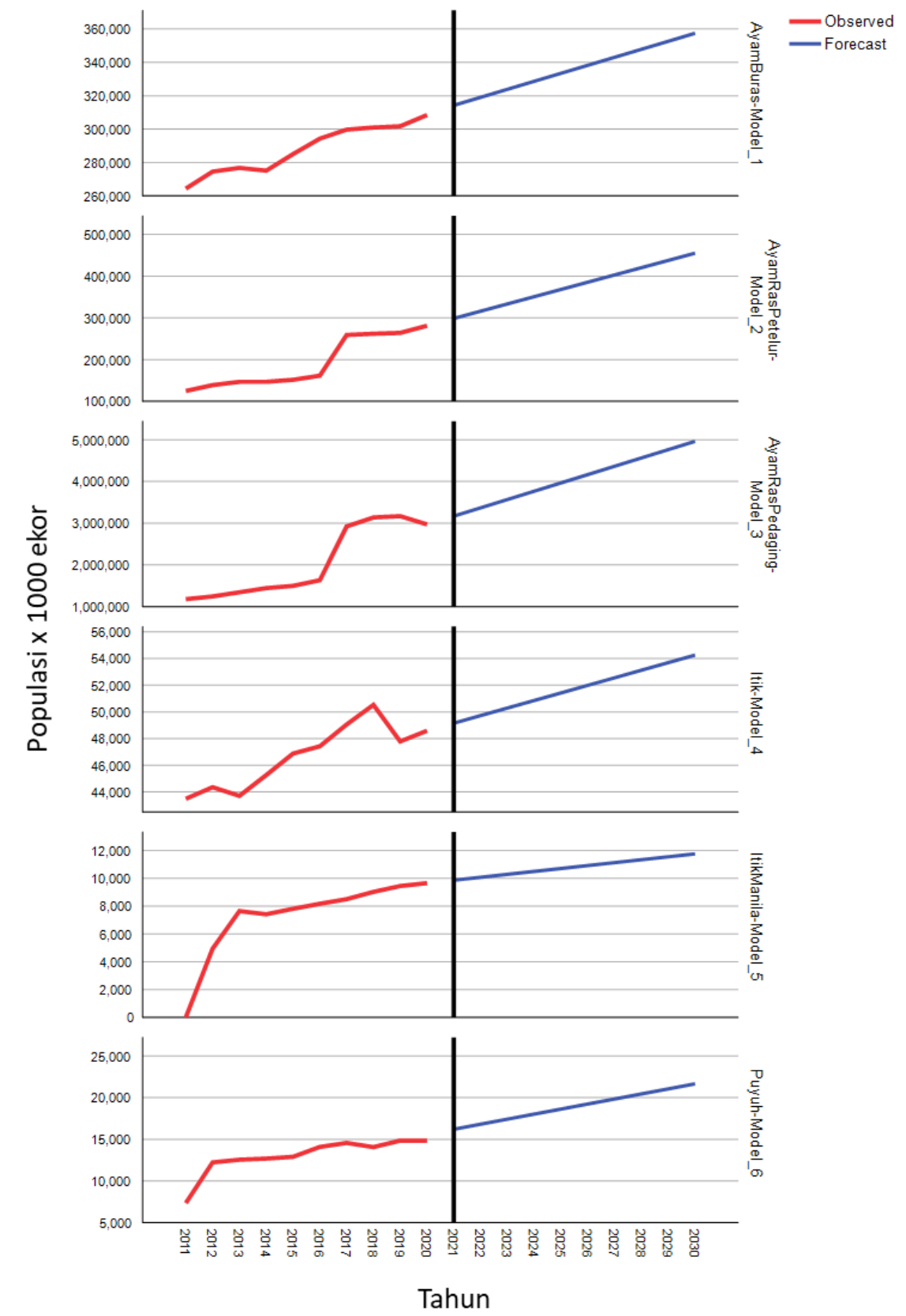

Gambar 3. Tren perkembangan populasi ternak unggas di Indonesia.

Populasi kambing dan domba memiliki tren yang hampir sama (Gambar 1). Peningkatan terjadi dari tahun 2011 hingga 2015 kemudian menurun pada tahun 2016 dan meningkat kembali hingga saat ini. Penurunan yang terjadi pada tahun 2016 diakibatkan faktor krisis bibit akibat peminatan daging kambing dan domba yang meningkat. Hal ini dapat dilihat dari data konsumsi daging kambing dan domba meningkat pada tahun 2017 (Ditjen PKH 2020). Seperti yang dituliskan oleh Kuda (2020) bahwa budidaya kambing dan domba masih dilakukan oleh peternak kecil, sehingga logis jika pengadaan bibit tidak dapat mengimbangi peningkatan permintaan pasar. Selama ini segmentasi peminatan domba dan kambing sebagian besar adalah untuk aqiqah dan kurban.

Berdasarkan hasil analisis peramalan yang kami lakukan, hingga tahun 2030 populasi sapi potong, kambing, dan domba serta produksi daging akan semakin meningkat setiap tahunnya. 
Fuadi \& Sugiarto (2019) berpendapat bahwa swasembada daging dapat tercapai pada tahun 2026, didasarkan pada program UPSUS SIWAB tahun 2016. Total populasi penduduk Indonesia tahun 2020 adalah 270 juta jiwa dengan peningkatan sebesar 1\% dari tahun 2019 . Konsumsi daging sapi rata-rata $2,7 \mathrm{~kg} / \mathrm{kapita} /$ tahun (Agus \& Widi, 2018). Jika peningkatan stabil, maka total populasi penduduk Indonesia pada tahun 2030 di prediksi mencapai 297 juta jiwa. Berdasar perkiraan data produksi daging (ruminansia dan unggas) tahun 2030 terdapat 7 juta ton/ tahun. Tren peningkatan prediksi produksi daging total banyak disumbang dari sektor unggas (Gambar 2). Populasi ternak unggas di antaranya ayam buras, ayam ras, itik, itik manila, dan puyuh memiliki tren peningkatan dari tahun ke tahun (Gambar 3). Penurunan semua populasi komoditas hanya terjadi pada masa pandemi Covid 19 tahun 2019 kecuali populasi itik yang juga menurun pada tahun 2014.

Konsumsi daging diperkirakan naik hingga $5 \mathrm{~kg} / \mathrm{kapita}$ pada tahun 2030. Data tersebut menunjukkan bahwa, Indonesia belum dapat mencukupi kebutuhan konsumen dengan komoditas ternak lokal. Sejalan dengan hasil ini, Agus \& Widi (2018) menggambarkan perkiraan pemenuhan kebutuhan daging Indonesia belum dapat terpenuhi hingga 2024. Hasil analisis terhadap populasi komoditas sapi perah dan kerbau serta produksi susu yang diprediksi stagnan (Gambar 1). Populasi kerbau yang menurun tajam pada tahun 2018 mengakibatkan pola grafik peramalan yang tidak meningkat hingga 10 tahun ke depan. Sedangkan pada ternak perah, permasalahan yang sering dijumpai adalah minimnya penerapan management practice (Khasanah \& Widianingrum, 2021). Wilayah di Indonesia yang beriklim tropis, juga menjadi faktor pembatas peningkatan populasi ternak perah mengingat banyaknya kendala teknologi dan sapi perah jenis $\mathrm{FH}$ membutuhkan lingkungan dengan udara sejuk untuk dapat tumbuh dan berproduksi secara optimal. Berdasar perhitungan perbandingan efisiensi dan biaya total usaha, diketahui bahwa pemeliharaan sapi perah lebih menguntungkan peternak dibanding usaha penggemukan sapi potong (Musriawati, Badriah, \& Kadarwati, 2020; Marchani, 2021).

Berdasar data persebaran populasi ternak , sapi potong, sapi perah, kerbau, domba, kambing, ayam ras (petelur dan pedaging), ayam buras, puyuh, itik, dan itik manila (Tabel 2). Diketahui bahwa Provinsi Jawa Timur memiliki populasi nasional tertinggi untuk komoditas sapi perah, sapi potong, dan ayam ras petelur; Jawa Tengah memiliki komoditas kambing, puyuh, dan ayam buras tertinggi; Jawa Barat mendominasi komoditas domba, ayam ras pedaging, itik, dan itik manila; serta kerbau didominasi di Provinsi Nusa Tenggara.

Permasalahan yang terjadi di lapangan adalah pada daerah dengan populasi tinggi, banyak peternakan yang dilaporkan dijalankan dengan manajemen pemeliharaan yang belum optimal (Firman, Marina, \& Paturachman, 2017; Agus \& Widi, 2018). Sebagian besar peternak kecil masih melakukan sistem pemeliharaan skala rakyat dan hanya bertujuan untuk pekerjaan sampingan (Hartono \& Rohaeni, 2014). Pada penelitian tersebut dijelaskan bahwa peternak kecil (petani sekaligus peternak) dengan jumlah ternak potong rata-rata 4-5 ekor telah melakukan usahanya selama 11-20 tahun, memiliki keuntungan 3-4 juta rupiah selama pemeliharaannya. Hal serupa juga dilaporkan di peternakan perah di Jawa Timur (Khasanah \& Widianingrum, 2021). Provinsi Jawa Timur memiliki komoditas ternak yang tinggi, termasuk ayam ras petelur. Hal ini didukung oleh banyaknya perusahaan dari hulu ke hilir di daerah ini (Dinas Peternakan Jawa Timur, 2020). Ayam ras pedaging banyak dijumpai di Jawa Barat baik mandiri maupun peternak plasma (Saptana, Maulana, \& Ningsih, 2017).

Provinsi Jawa Timur juga memiliki populasi itik dan itik manila tertinggi. Kamilah (2015) menganalisis keuntungan yang didapatkan dari pemeliharaan itik dengan total populasi 3700 ekor dapat mencapai 22 juta rupiah per tahun. Produktivitas ayam kampung lebih rendah dibandingkan dengan ayam ras. Kelemahan ini perlu diperbaiki dengan seleksi dan peningkatan mutu yang lainnya termasuk pakan dan manajemen. Hal ini penting dilakukan mengingat bahwa ayam lokal mempunyai potensi untuk dapat menambah suplai ketersediaan daging dan telur di samping produksi ayam ras. Provinsi Jawa Tengah memiliki potensi pengembangan komoditas ayam kampung. Diseminasi budidaya ayam kampung unggul balitbangtan (KUB) di Jawa Tengah dilakukan oleh Hidayah, Ambarsari, \& Subiharta (2019). Komoditi lain, yaitu puyuh juga sangat prospek dikembangkan di Jawa Tengah. 
Tabel 2. Sepuluh besar provinsi dengan populasi ternak ruminansia tertinggi nasional (x1000 ekor)

\begin{tabular}{|c|c|c|c|c|c|c|c|c|c|c|}
\hline No & Provinsi & Sapi Potong & Provinsi & Sapi Perah & Provinsi & Kerbau & Provinsi & Kambing & Provinsi & Domba \\
\hline 1 & Jatim & 4615557,4 & Jatim & 283405,8 & NTT & 155779 & Jateng & 4028282,6 & Jabar & 11573661 \\
\hline 2 & Jateng & 1744947 & Jateng & 142044,2 & Aceh & 121293,2 & Jatim & 3456363,6 & Jateng & 2388300,4 \\
\hline 3 & Sulsel & 1379460 & Jabar & 118987,8 & NTB & 115178,2 & Lampung & 1411403 & Jatim & 1381413,8 \\
\hline 4 & NTB & 1189023,4 & DI. Yogyakarta & 3845,8 & Sulsel & 109465,6 & Jabar & 1298052,8 & Sumut & 704068,8 \\
\hline 5 & NTT & 1059229 & Sumut & 3288,8 & Sumut & 104885 & Sumut & 880884,8 & Banten & 571203,6 \\
\hline 6 & Sumut & 833170 & DKI Jakarta & 2075,8 & Sumbar & 95200 & Sulsel & 777080,8 & Yogyakarta & 162313,4 \\
\hline 7 & Lampung & 776431,4 & Sulsel & 1420,6 & Jabar & 83908,2 & Banten & 771573 & Aceh & 100681,8 \\
\hline 8 & Bali & 549643,4 & Sumbar & 762 & Banten & 76182,8 & NTT & 765948,4 & Lampung & 75344 \\
\hline 10 & Sumbar & 404700,6 & Bengkulu & 254,6 & Jambi & 41470,4 & Aceh & 622666 & NTT & 65736 \\
\hline
\end{tabular}

Tabel 3. Sepuluh besar provinsi dengan populasi ternak unggas tertinggi nasional (x1000 ekor)

\begin{tabular}{|c|c|c|c|c|c|c|c|c|c|c|c|c|}
\hline No & Provinsi & Ayam Buras & Provinsi & Ayam Layer & Provinsi & Ayam Broiler & Provinsi & Itik & Provinsi & Itik manila & Provinsi & Puyuh \\
\hline 1 & Jateng & 41775809 & Jatim & 78567450,6 & Jabar & 721443059,6 & Jabar & 9290255,8 & Jabar & 2156493,8 & Jateng & 4566717,6 \\
\hline 2 & Jatim & 37840715,4 & Jabar & 30500376,2 & Jateng & 467389760,6 & Jatim & 5908200,2 & Sulsel & 1574107 & Jatim & 3754900,8 \\
\hline 3 & Sulsel & 30018556,8 & Jateng & 28307661,2 & Jatim & 393518473,6 & Sulsel & 5543059,2 & Jatim & 1499153 & Yogyakarta & 1904704 \\
\hline 4 & Jabar & 26869399 & Sumut & 24334899,4 & Banten & 194853612,4 & Jateng & 5250598 & Jateng & 1475320 & Sumbar & 1424610,6 \\
\hline 5 & Sumut & 15547997,2 & Sumbar & 12461091,4 & Sumut & 135748106,2 & Kalsel & 4403179,2 & Sumut & 680793 & Jabar & 919884,8 \\
\hline 6 & Jambi & 14177049,8 & Banten & 11110315,8 & Riau & 80844925,4 & Sumut & 2658944,6 & Aceh & 474531,8 & Kalsel & 461152,4 \\
\hline 7 & Lampung & 12735162,6 & Sulsel & 10010318,8 & Kalsel & 79567816,8 & Aceh & 2310120,4 & Banten & 172807,8 & Sumut & 264539,6 \\
\hline 9 & $\begin{array}{l}\text { Sulawesi } \\
\text { Tenggara }\end{array}$ & 10051342,8 & Sumsel & 8642922,8 & Sumsel & 78515908,2 & Banten & 1799642,2 & Bengkulu & 99218 & $\begin{array}{c}\text { Sulawesi } \\
\text { Utara }\end{array}$ & 152619,8 \\
\hline 10 & Kalsel & 9875854,2 & Lampung & 6102250,6 & Lampung & 74415693 & Sumbar & 1165024,2 & Papua & 69044,4 & Riau & 118411 \\
\hline
\end{tabular}


Pemasok utama puyuh berasal dari Provinsi Jawa Tengah, Jawa Timur, dan Yogyakarta untuk selanjutnya disebar ke Jabodetabek (Wuryadi, 2013).

Produktivitas ayam kampung lebih rendah dibandingkan dengan ayam ras. Kelemahan ini perlu diperbaiki dengan seleksi dan peningkatan mutu yang lainnya termasuk pakan dan manajemen. Hal ini penting dilakukan mengingat bahwa ayam lokal mempunyai potensi untuk dapat menambah suplai ketersediaan daging dan telur di samping produksi ayam ras. Provinsi Jawa Tengah memiliki potensi pengembangan komoditas ayam kampung. Diseminasi budidaya ayam kampung unggul balitbangtan (KUB) di Jawa Tengah dilakukan oleh Hidayah, Ambarsari, \& Subiharta, 2019). Komoditi lain, yaitu puyuh juga sangat prospek dikembangkan di Jawa Tengah. Pemasok utama puyuh berasal dari Provinsi Jawa Tengah, Jawa Timur, dan Yogyakarta untuk selanjutnya disebar ke Jabodetabek (Wuryadi, 2013).

Strategi peningkatan produksi ternak dapat dilakukan melalui berbagai cara. Beberapa di antaranya yaitu optimalisasi dengan sistem integrasi sumber pakan lokal (Indrayani \& Hellyward, 2015), peningkatan teknologi (Andria, Effendi, \& Maesya, 2017; Purwantini, 2015), pola kemitraan (Pramita, Kusnadi \& Harianto, 2017), optimasi wilayah dengan populasi tinggi (Dewi \& Subagja, 2015), peningkatan usaha peternakan di wilayah strategis lain (Darsono, Putri, \& Nahrowi, 2016; Yuniar, Fuah, \& Widiatmaka, 2016). Strategi praktis guna meningkatkan kesehatan dapat dilakukan dengan cara perbaikan manajemen kesehatan termasuk di dalamnya kebersihan kandang, kontrol penyakit, program vaksinasi, pemberian fitobiotik sebagai imunomodulator alami (Khasanah, Silaban, Priyono, 2021; Widianingrum \& Salasia, 2021).

\section{KESIMPULAN}

Berdasarkan data dan analisis di atas, maka dapat disimpulkan bahwa tren sistem usaha peternakan di Indonesia dengan tujuan komersial masih perlu ditingkatkan. Strategi peningkatan produksi dapat dilakukan dengan optimalisasi sistem integrasi sumber pakan lokal, peningkatan teknologi, pola kemitraan, optimasi wilayah dengan populasi tinggi, peningkatan usaha peternakan di wilayah strategis lain. Kondisi ini jika dapat diterapkan, maka wilayah yang telah memiliki populasi tertinggi nasional akan menghasilkan produktivitas ternak yang lebih tinggi dan pemerataan produksi ternak akan tercapai di seluruh Provinsi Indonesia.

\section{DAFTAR PUSTAKA}

Abdul, H. H. (2016). Dinamika Populasi Ternak Kerbau Di Kecamatan Panyabungan Kabupaten Mandailing Natal. Universitas Andalas, Padang.

Afrizal, A., \& Pulungan, R. E. (2014). Dampak Kebijakan Indonesia Membatasi Kuota Impor Daging Sapi dari Australia. Universitas Riau, Riau.

Agus, A., \& Widi, T. S. M. (2018). Current situation and future prospects for beef cattle production in Indonesia-A review. Asian-Australasian journal of animal sciences, 31(7), 976. https://doi.org/10.5713/ajas.18.0233

Andria, F., Effendi, E. M., \& Maesya, A. (2017). Otomatisasi Mesin Tetas Telur Puyuh Untuk Optimasi Pembibitan, Peningkatan Produksi Dan Pemasaran Bagi Peternak Puyuh. Qardhul Hasan: Media Pengabdian Kepada Masyarakat, 3(2), 107-121. https://doi.org/ 10.30997/gh.v3i2.946.

Anggraini, N. \& Putra, R. A. (2017). Analisis potensi wilayah dalam pengembangan peternakan sapi potong di Kecamatan Sijunjung Kabupaten Sijunjung. Agrifo: Jurnal Agribisnis Universitas Malikussaleh, 2(2), 82-100. https://doi.org/10.29103/ag.v2i2.380

Ariningsih, E. (2014). Kinerja kebijakan swasembada daging sapi nasional. In Forum Penelitian Agro Ekonomi, 32(2), 137-156. https://doi.org/10.21082/fae.v32n2.2014.137-156.

Asmarantaka, R. W., \& Nurmalina, R. (2021). Volatilitas dan transmisi harga daging sapi di indonesia: studi kasus di jakarta, Bandung, Semarang dan Surabaya. Buletin IImiah Litbang Perdagangan, 15(1), 127-156. https://doi.org/10.30908/bilp.v15i1.491

Badan Ketahanan Pangan. 2020. Direktori Perkembangan Konsumsi Pangan. Retrieved July, 23, 2021 from http://bkp.pertanian.go.id/storage/app/media/Bahan\%202020/panduan-teknis- 
prognosa-2020-final2.pdf.

Badan Pusat Statistik. (2020). Hasil sensus penduduk. Retrieved July 22, 2021, from https://www.bps.go.id/pressrelease/2021/01/21/1854/hasil-sensus-penduduk-2020.html

Darsono, W., Putri, E. I. K., \& Nahrowi, N. (2016). Prioritas Wilayah Pengembangan Ternak Ruminansia di Kabupaten Tasikmalaya The Priority Region of Ruminant Development in Tasikmalaya District. Jurnal IImu Produksi dan Teknologi Hasil Peternakan, 4(3), 356-363. ISSN 2303-2227.

Delgado, C., Rosegrant, M., Steinfeld, H., Ehui, S., Courbuis, C. (2012). Livestock to 2020: the next food revolution. Outlook on Agric, 30:27-9. Tokyo: International Food Policy Research Institute

Dewi, N. D. A. K., \& Subagja, H. (2015). Analisis Program Penyuluhan, Sumber Daya Manusia Pada Optimalisasi IB Dan Sarana Prasarana Perluasan Lahan HMT Terhadap Peningkatan Produksi Sapi Potong Di Kabupaten Bondowoso. Jurnal IImiah Inovasi, 15(3). https://doi.org/ 10.25047/jii.v15i3.14.

Dinas Peternakan Jawa Timur. 2020. Perusahaan Peternakan di Jawa Timur. Retrieved July, 23, 2021 from https://disnak.jatimprov.go.id/web/usahapeternakan/duniausahapeternakan.

Direktorat Jenderal Peternakan dan Kesehatan Hewan/ Ditjen PKH. 2020. Statistik Peternakan dan Kesehatan Hewan 2020. Retrieved July 22, 2021, from https://ditjenpkh.pertanian.go.id/userfiles/download/f18748813ab4f89601dedf7d3ee84e12.pdf

Firman, A., Marina, S., Paturachman, S., \& Linda, H. (2017). Evaluation of good dairy farming practice method on dairy farming in Subang District, West Java, Indonesia. International Seminar on Livestock Production and Veterinary Technology, 204-212. Bogor: Proceeding of international seminar on Livestock production and Veterinary Technology.

Fuadi, Y., \& Sugiarto, S. (2019). Menuju Swasembada Daging Sapi. Seminar Nasional Official Statistics, 2019(1), 152-160. Jakarta.

Hartono, B., \& Rohaeni, E. S. (2014). Contribution to income of traditional beef cattle farmer households in Tanah Laut Regency, South Kalimantan, Indonesia. Livestock Research for Rural Development, 26(8), 141-5.

Hidayah, R., Ambarsari, I., \& Subiharta, S. (2019). Kajian Sifat Nutrisi, Fisik dan Sensori Daging Ayam KUB di Jawa Tengah. Jurnal Peternakan Indonesia (Indonesian Journal of Animal Science), 21(2), 93-101.

Ilham, N. (2019). Fluktuasi Harga Telur Ayam Ras dan Faktor Penyebabnya. Analisis Kebijakan Pertanian, 17(1), 27-38. http://dx.doi.org/10.21082/akp.v17n1.2019.27-38

Ilham, N. (2020). Pengembangan rantai pasok daging ayam secara terpadu di Jawa Barat dan Jawa Timur. Analisis Kebijakan 41-57. http://dx.doi.org/10.21082/akp.v18n1.2020.41-57

Indrayani, I., \& Hellyward, J. (2015). Optimalisasi produksi dan maksimalisasi keuntungan usaha ternak sapi potong dengan sistem integrasi sapi-sawit di Kabupaten Dharmasraya. Jurnal Peternakan Indonesia (Indonesian Journal of Animal Science), 17(3), 187-194. https://doi.org/10.25077/ipi.17.3.187-194.2015

Kamilah, D. I. (2015). Analisis Fungsi Keuntungan Usaha Itik Pedaging (Sensus Di Kelompok Bahana Putra Mandiri dan Prima Karya Mandiri Kabupaten Tasikmalaya). Students eJournal, 4(2).

Khasanah, H., \& Widianingrum, D. C. (2021). Management practices related to the incidence of sub clinical mastitis (SCM) in lactating dairy cow in Banyuwangi, Indonesia. The 4rd International Conference and Life Science 2020. Jember. IOP Conference Series: Earth and Environmental Science 759.

Khasanah, H., Purnamasari, L., \& Suciati, L. P (2020). Pengembangan Pembibitan Kambing Peranakan Etawah di Wonosari, Kabupaten Jember. Indonesian Journal of Community Engagement, 6(3), 162-169. https://doi.org/10.22146/jpkm.52806

Khasanah, H., Silaban, D. G., Priyono, A., Dinar, A., Nashrullah, L., \& Syaikhullah, G. (2021). Strategi Praktis Penanganan Egg Drop Syndrome pada Ayam Petelur. Jurnal Sain Peternakan Indonesia, 16(2), 202-209. https://doi.org/10.31186/ispi.id.16.2.202-209

Kuda, K. K. D. B. (2020). IImu dan Manajemen Ternak Pedaging. Universitas Brawijaya Press. 
Kusmaria, Susanti, Fitri, A., \& Handayani, S. (2020). Kajian Kebijakan Daging Sapi Di Indonesia Untuk Mendukung Swasembada Daging Sapi. dwijenAGRO, 10(1), 27-39. https://doi.org/10.46650/dwijenagro.10.1.860.27-39.

Latino, L. R., Pica-Ciamarra, U., \& Wisser, D. (2020). Africa: The livestock revolution urbanizes. Global food security, 26, 100399. https://doi.org/10.1016/i.gfs.2020.100399.

Liga, L. B. R. T. Putri., N. G. Sumardani. 2019. Strategi Pemulihan Usaha Peternakan Sapi Bali pada Wilayah Terdampak Erupsi Gunung Agung di Kabupaten Karangasem. Journal of Tropical Animal Science, 7(1), 836-850.

Marchani, I. I. (2021). Analisis Perbandingan Finansial Usaha Peternakan Sapi Perah Bangkingan Dan Sapi Potong Lidah Kulon. Universitas 17 Agustus 1945, Surabaya.

Mishra, P., Matuka, A., Abotaleb, M. S. A., Weerasinghe, W. P. M. C. N., Karakaya, K., \& Das, S. S. (2021). Modeling and forecasting of milk production in the SAARC countries and China. Modeling Earth Systems and Environment, 1-13. https://doi.org/10.1007/s40808-02101138-z

Musriawati, D. R., Badriah, L. S., \& Kadarwati, N. (2020). Perbandingan Keuntungan Dan Efisiensi Ekonomi Usaha Ternak Sapi Perah Dan Sapi Potong (Studi Kasus Di Desa Limpakuwus Kecamatan Sumbang Kabupaten Banyumas). Prosiding Seminar Teknologi Agribisnis Peternakan (Stap) Fakultas Peternakan Universitas Jenderal Soedirman. 7, 129137. Purwokerto.

Nair, A. S., Thirunavukkarasu, M., Pandian, A. S. S., Senthilkumar, G., \& Balan, C. (2019). Forecasting Livestock and Poultry Production in India. Indian Journal of Veterinary and Animal Sciences Research, 48(4), 9-21.

Pramita, D. A., Kusnadi, N., \& Harianto, H. (2017). Efisiensi Teknis USAha Ternak Ayam Broiler Pola Kemitraan di Kabupaten Limapuluh Kota. Jurnal Agribisnis Indonesia, 5(1), 1-10.

Purwantini, T. B. (2015). Optimalisasi Inseminasi Buatan (IB) mendukung percepatan produksi dan swasembada daging sapi. Prosiding Seminar Nasional Pengembangan Teknologi Pertanian, 602-209. Lampung.

Rorimpandey, B., Lenzun, G. D., \& Endoh, E. K. M. (2014). Analisis Pengaruh Pendapatan Rumah Tangga Terhadap Konsumsi Daging Dan Telur Di Kecamatan Suluun Tareran Kabupaten Minahasa Selatan. Zootec, 34(1), 37-47. ISSN 0852-2626.

Rozani, M. K., Agustin, N., Adhani, Y., Agustini, H., \& Syukur, A. (2021). Optimalisasi Hasil Produksi Susu Kambing Peranakan Etawa Melalui Ekonomi Kratif Berbasis Mitra Untuk Mendukung Pariwasata. Jurnal Pengabdian Magister Pendidikan IPA, 4(2). https://doi.org/ 10.29303/ipmpi.v4i2.721.

Rusdiana S, Soeharsono. 2017. UPSUS SIWAB Program for increasing beef cattle population and economical value of livestock enterprise. Forum Penelitian Agro Ekonomi. 35, 125-37.

Saliem, H. P., Agustian, A., \& Perdana, R. P. (2020). Dinamika harga, permintaan, dan upaya pemenuhan pangan pokok pada era pandemi Covid-19. Buku Bunga Rampai Covid-19. Bogor (ID): Pusat Sosial Ekonomi dan Kebijakan Pertanian.

Santoso, B. (2020). Prospek Pengembangan Sapi Potong di Era Normal Baru Pasca Pandemi Covid-19. Prosiding Seminar Teknologi Agribisnis Peternakan (Stap) Fakultas Peternakan Universitas Jenderal Soedirman. 7, 15-23. Purwokerto.

Saptana, S., Maulana, M., \& Ningsih, R. (2017). Produksi dan pemasaran komoditas broiler di Jawa Barat. Jurnal Manajemen \& Agribisnis, 14(2), 152-152. https://doi.org/10.17358/jma.14.2.152

Setyawan, H. B., Widianingrum, D. C., Yulianto, R., \& Khasanah, H. (2021). Robustness of dairy cattle farming industry against Covid-19 pandemic in business group (KUB) Tirtasari Kresna Gemilang, Malang. In IOP Conference Series: Earth and Environmental Science (Vol. 759, No. 1, p. 012056). IOP Publishing.

Widianingrum, D. C., \& Salasia, S. I. O. (2021). Immunomodulatory Effect of Virgin Coconut Oil in Wistar Rats Infected with Staphylococcus aureus. Jurnal IImu Ternak dan Veteriner, 26(1), 3138. http://dx.doi.org/10.14334/jitv.v26i1.2670

Wuryadi, S. (2013). Beternak Puyuh. JAwa Barat: AgroMedia.

Yuniar, P. S., Fuah, A. M., \& Widiatmaka, W. (2016). Daya Dukung dan Prioritas Wilayah 
Widianingrum \& Khasanah

Conference of Applied Animal Science 2021

Pengembangan Ternak Sapi Potong di Kota Tangerang Selatan. Jurnal Ilmu Produksi dan Teknologi Hasil Peternakan, 4(1), 264-268. ISSN 2303-2227. 